\title{
Recent advances in understanding and managing chronic
}

\section{constipation [version 1; peer review: 2 approved]}

\author{
David O. Prichard (D1, Adil E. Bharucha(iD)2
}

${ }^{1}$ Division of Gastroenterology and Hepatology, Mayo Clinic, 200 1st Street SW, Rochester, MN 55905, USA

${ }^{2}$ Clinical Enteric Neuroscience Translational and Epidemiological Research Program and Division of Gastroenterology and Hepatology, Mayo Clinic, 200 1st Street SW, Rochester, MN 55905, USA

V1 First published: 15 Oct 2018, 7(F1000 Faculty Rev):1640

https://doi.org/10.12688/f1000research.15900.1

Latest published: 15 Oct 2018, 7(F1000 Faculty Rev):1640

https://doi.org/10.12688/f1000research.15900.1

\section{Abstract}

Constipation, a condition characterized by heterogeneous symptoms, is common in Western society. It is associated with reduced physical health, mental health, and social functioning. Because constipation is rarely due to a life-threatening disease (for example, colon cancer), current guidelines recommend empiric therapy. Limited surveys suggest that fewer than half of treated individuals are satisfied with treatment, perhaps because the efficacy of drugs is limited, they are associated with undesirable side effects, or they may not target the underlying pathophysiology. For example, although a substantial proportion of constipated patients have a defecatory disorder that is more appropriately treated with pelvic floor biofeedback therapy than with laxatives, virtually no pharmacological trials formally assessed for anorectal dysfunction. Recent advances in investigational tools have improved our understanding of the physiology and pathophysiology of colonic and defecatory functions. In particular, colonic and anorectal high-resolution manometry are now available. Highresolution anorectal manometry, which is increasingly used in clinical practice, at least in the United States, provides a refined assessment of anorectal pressures and may uncover structural abnormalities. Advances in our understanding of colonic molecular physiology have led to the development of new therapeutic agents (such as secretagogues, pro-kinetics, inhibitors of bile acid transporters and ion exchangers). However, because clinical trials compare these newer agents with placebo, their efficacy relative to traditional laxatives is unknown. This article reviews these physiologic, diagnostic, and therapeutic advances and focuses particularly on newer therapeutic agents.

\section{Keywords}

Constipation, diagnosis, management, lubiprostone, linaclotide, plecanatide, prucalopride, velusetrag, elobixibat, NGM282, tenapanor

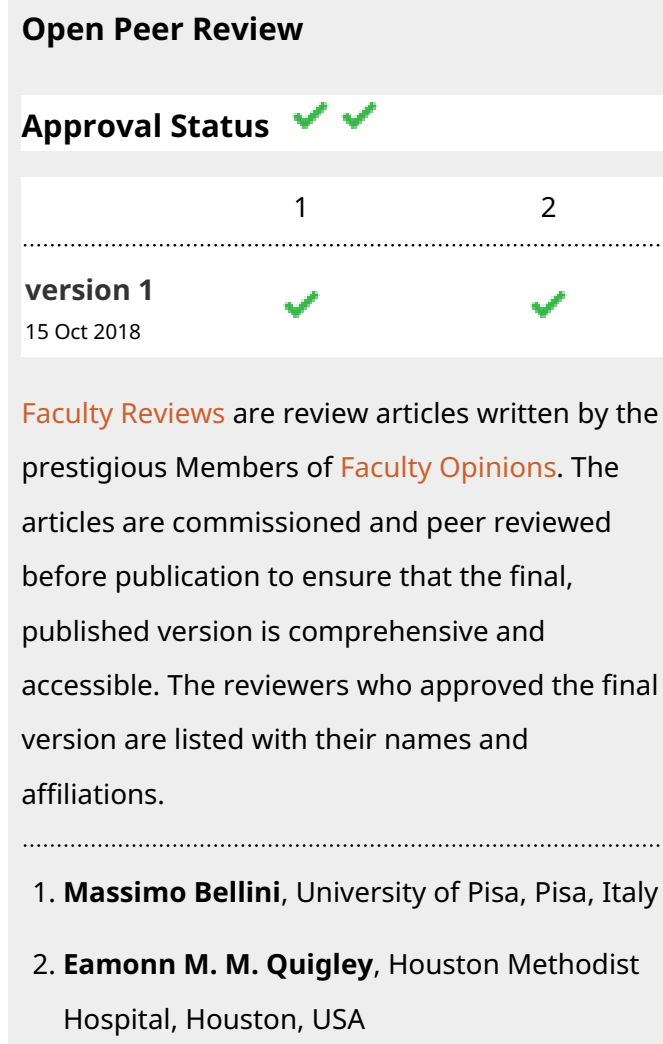

1. Massimo Bellini, University of Pisa, Pisa, Italy

2. Eamonn M. M. Quigley, Houston Methodist Hospital, Houston, USA

Any comments on the article can be found at the end of the article. 
Corresponding author: Adil E. Bharucha (bharucha.adil@mayo.edu)

Author roles: Prichard DO: Conceptualization, Writing - Original Draft Preparation, Writing - Review \& Editing; Bharucha AE: Conceptualization, Writing - Original Draft Preparation, Writing - Review \& Editing

Competing interests: AEB has received consulting fees from Asubio Pharmaceuticals, Ironwood Pharmaceuticals, Galcare

Pharmaceuticals, and Medspira and has licensed patents to Medspira and Medtronic. DOP declares that he has no competing interests.

Grant information: This work was supported in part by US Public Health Service National Institutes of Health grant P01 DK68055.

The funders had no role in study design, data collection and analysis, decision to publish, or preparation of the manuscript.

Copyright: ( 2018 Prichard DO and Bharucha AE. This is an open access article distributed under the terms of the Creative Commons Attribution License, which permits unrestricted use, distribution, and reproduction in any medium, provided the original work is properly cited.

How to cite this article: Prichard DO and Bharucha AE. Recent advances in understanding and managing chronic constipation [version 1; peer review: 2 approved] F1000Research 2018, 7(F1000 Faculty Rev):1640 https://doi.org/10.12688/f1000research.15900.1

First published: 15 Oct 2018, 7(F1000 Faculty Rev):1640 https://doi.org/10.12688/f1000research.15900.1 


\section{Background}

Symptoms of constipation are reported by $10 \%$ to $20 \%$ of adults worldwide". Classically, the term "constipation" refers to infrequent bowel motions or hard feces. However, the disorder is heterogeneous; patients report a variety of symptoms including reduced bowel motion frequency, straining, hard stools, the sensation of incomplete emptying, the sensation of anal blockage, or the use of digitation or positioning to aid defecation (Box 1)2. In affected individuals, physical health, mental health, and social functioning are reduced ${ }^{3,4}$. Despite this, only one-fifth of constipated individuals seek health-care advice $^{5}$. Yet, given the high prevalence of this condition, this represents over 8 million health-care visits ${ }^{6}$ and $\$ 230$ million in costs $^{7}$ annually in the United States.

\section{Box 1. Diagnostic criteria for functional constipation \\ Two or more of the following must be present \\ I. Straining during more than one-fourth $(25 \%)$ of defecations \\ II. Lumpy or hard stools (Bristol Stool Form Scale 1-2) in more than one-fourth $(25 \%)$ of defecations \\ III. Sensation of incomplete evacuation in more than one- fourth $(25 \%)$ of defecations \\ IV. Sensation of anorectal obstruction/blockage in more than one-fourth (25\%) of defecations \\ V. Manual maneuvers to facilitate more than one-fourth (25\%) of defecations (for example, digital evacuation and support of the pelvic floor) \\ VI. Fewer than three spontaneous bowel movements per week}

These criteria must be fulfilled for the previous 3 months. The symptom onset must be at least 6 months prior to diagnosis.

In addition

I. Loose stools are rarely present without the use of laxatives

II. There are insufficient criteria for irritable bowel syndrome

Based upon Mearin et al. ${ }^{2}$

In the absence of alarm features, constipation is seldom due to a life-threatening organic disorder (for example, colon cancer) or another disease (for example, hypothyroidism). Hence, guidelines recommend initial empiric therapy for constipated patients rather than investigating for a cause (for example, with colonoscopy $)^{8,9}$. Likewise, although primary constipation generally results from slow colonic transit, impaired rectal evacuation, or both $^{8}$, tests to evaluate these processes are recommended only in patients who do not respond to laxatives.

Slow colonic transit is associated with hard stools ${ }^{10}$. Consequently, osmotic and stimulant laxatives are the two most commonly prescribed agents ${ }^{11,12}$. Osmotic laxatives (for example, polyethylene glycol or lactulose) retain water in the intestinal lumen, accelerating colonic transit and reducing the consistency of evacuated stool. Stimulant laxatives (for example, senna, bisacodyl, or glycerin) stimulate colonic contractions and the urge to defecate. Although laxatives increase bowel motion frequency ${ }^{13}$, satisfaction is variable ${ }^{14}$. In an internet-based survey of 1,355 patients with self-reported constipation in 10 European countries in 2009, 855 patients were taking laxatives. Of these patients, $28 \%$ were very satisfied or satisfied with their treatment, $44 \%$ were neutral, and $28 \%$ were dissatisfied with therapy. In particular, the symptom of bloating persists ${ }^{15}$. Conceptually, satisfaction may be suboptimal because the efficacy of drugs is limited, they are associated with undesirable side effects, or they may not target the underlying pathophysiology. In particular, a substantial proportion of constipated patients have a defecatory disorder that may be associated with normal or slow colonic transit. Defecatory disorders are more appropriately treated with pelvic floor biofeedback therapy than with laxatives ${ }^{16-18}$.

\section{Advances in understanding the molecular pathophysiology of constipation}

Abnormalities of ion channels within the intestine have been shown to affect secretion, absorption, motility, and sensation, potentially resulting in constipation, diarrhea, and irritable bowel syndrome (IBS) ${ }^{19}$. The presence of these dysfunctional channels may be suggested by a family history of a functional bowel disorder" 19 . Documented "channelopathies" include those affecting the voltage-gated sodium channel $\mathrm{Na}_{\mathrm{v}} 1.5$, present on smooth muscle cells; the voltage-gated sodium channels $\mathrm{Na}_{\mathrm{v}} 1.7$ and $\mathrm{Na}_{\mathrm{v}} 1.9$, present on neurons; and ion exchange channels, present on enterocytes ${ }^{19}$. Altered ion channel expression or function occurs because of genetic mutations, posttranslational modification, or accessory protein malfunction. In particular, the voltage-gated sodium channel $\mathrm{Na}_{\mathrm{v}} 1.5$ has been associated with constipation ${ }^{20}$. In one study, mutations, predominantly resulting in loss of function, were found in $7 \%$ of patients (4 out of 59) with constipation-predominant IBS $(\text { IBS-C })^{20}$. Further studies are necessary to determine whether these mutations were responsible for the bowel symptoms.

In selected studies, about one in four patients with diarrheapredominant IBS has high concentrations of fecal bile acids ${ }^{21}$. Conversely, a small fraction (that is, about $6 \%$ ) of patients with IBS-C have low fecal concentrations of bile acids ${ }^{22}$. It is unclear to what extent these findings represent a primary disturbance (that is, due to reduced secretion or increased reabsorption or both) or are secondary to slow colon transit. Nonetheless, because bile acids stimulate colonic secretion of water and high-amplitude-propagated contractions ${ }^{23,24}$, it is hypothesized that a paucity of colonic bile acids may cause constipation. Indeed, the corollary is also true: excess bile acid administered orally $^{24}$ or modification of the enterohepatic recycling pathway ${ }^{25}$ can exert a laxative effect.

\section{Normal and abnormal colonic and anal structure and function}

Defecation is an intricate viscerosomatic process ${ }^{26}$, and the pathophysiology of defecatory disorders is heterogeneous. A clinical history is insufficient for differentiating the subtypes of constipation $^{27}$. A detailed digital rectal examination ${ }^{28}$ may suggest the presence of manometric features of a defecatory disorderpositive predictive value (PPV) of $97 \%$ and negative predictive value (NPV) of $37 \%$ - but is less useful for predicting an 
abnormal rectal balloon expulsion test (PPV of 33\% and NPV of $65 \%)^{29,30}$. Indeed, agreement among anorectal tests is variable, perhaps partly because they assess different aspects of structure or function or both ${ }^{31,32}$. Consequently, the Rome criteria recommend that when standard empiric laxative therapy fails to provide relief for patients with constipation, defecatory disturbances be documented with two tests ${ }^{32}$. However, where manometry or defecography is not available, a digital rectal examination and balloon expulsion test are sufficient for screening.

A detailed rectoanal manometry and rectal balloon expulsion test can provide information regarding rectoanal neuromuscular functions $^{33}$. Relative to water-perfused manometry, highresolution manometry is simpler to perform ${ }^{34}$. However, in clinical practice, the incremental utility of high-resolution manometry above water-perfused manometry is unclear ${ }^{33}$.

In contrast to high-resolution anorectal manometry, highdefinition anorectal manometry provides a three-dimensional evaluation of pressures within the anal canal. To date, relatively small studies suggest that high-resolution and high-definition anorectal manometry have similar performance characteristics for evaluating anorectal disorders ${ }^{35,36}$. In high-definition anorectal manometry, similar to high-resolution anorectal manometry, $70 \%$ of healthy individuals exhibit a dyssynergic manometry pattern during simulated evacuation ${ }^{36}$. More recent studies observed that both high-resolution and high-definition anorectal manometry can identify rectoceles, intra-anal intussusception, and rectal prolapse $\mathrm{e}^{37-40}$. However, whether these techniques will augment or supplant defecography, or fall by the wayside, for diagnosing these conditions has yet to be determined.

Within the colon, high-resolution manometry is better than standard water-perfused manometry for visualizing propagated colonic contractions ${ }^{41}$. While high-resolution colonic manometry remains primarily a research tool, attempts are being made to incorporate these data into clinical practice. For example, among 18 pediatric patients with slow transit constipation and six children with normal transit constipation, manometric findings were predictive of neuropathy with a sensitivity of $100 \%$ and a specificity of $86 \%{ }^{42}$.

Radiological tests are also useful for evaluating anorectal and colonic functions. Barium defecography is used to exclude or diagnose rectoceles and pelvic organ prolapse causing obstructed defecation. Magnetic resonance imaging (MRI) defecography offers a radiation-free alternative. Furthermore, it provides a comprehensive evaluation of pelvic organ structure and function during defecation without the need to instill radiopaque material into the small bowel, bladder, or vagina. With the exception of internal intussusception ${ }^{43}$ and retentive rectoceles ${ }^{44,45}$, which are less frequently identified during MRI defecography, barium and MRI defecography have similar performance characteristics.

MRI has been used as a research tool to evaluate colonic motor function in constipation and $\mathrm{IBS}^{46-48}$. Inoh et al. evaluated the relationship between colonic diameter and gastrointestinal symptoms in 20 patients with self-reported chronic constipation by using abdominal MRI ${ }^{49}$. Ascending colon diameter correlated with a sense of incomplete evacuation, and rectal diameter correlated with constipation scores ${ }^{49}$. However, although the sum of all the segmental diameters (cecum, ascending, transverse, descending, sigmoid colon, and rectum) correlated with an increasing severity of constipation, the sum of certain segmental diameters also positively correlated with diarrhea. Furthermore, no statistical adjustment appears to have been made for the multiple comparisons performed in this study. Although the hypothesis is interesting, further studies are required to understand the relationship among colonic fecal volume, colonic diameter, and bowel function. Park et al. demonstrated that rectal gas volume was a marker of defecatory disorders; at a specificity of $90 \%$, a rectal gas volume of $30 \mathrm{~mL}$ had a PPV of $77.3 \%$ for an evacuation disorder ${ }^{50,51}$.

\section{Development of novel therapeutic agents for the treatment of constipation}

A few medications that selectively target intestinal secretion or motility are available. Serotonin receptor agonists have been used to accelerate intestinal transit. Activation or inhibition of intestinal ionic transporters can increase luminal fluid content and accelerates the rate of colonic transit. Inhibition of ileal bile acid transporters exposes the colon to a greater concentration of these ionic detergents, resulting in the secretion of water into the colonic lumen and accelerated colonic transit.

\section{Selective 5-HT(4) receptor agonists: prucalopride and velusetrag}

Cisapride and tegaserod, the initial 5-HT(4) receptor agonists used to treat functional bowel disorders ${ }^{52,53}$, were withdrawn from the market because of cardiovascular events ${ }^{54-56}$. By targeting differing pharmacophores, with greater receptor selectivity, novel 5-HT(4) receptor agonists avoid this pro-arrhythmic risk ${ }^{57,58}$.

Prucalopride is a selective, high-affinity, 5-HT(4) receptor agonist with prokinetic gastrointestinal activity ${ }^{59}$. Prucalopride accelerated colonic transit in healthy individuals ${ }^{60,61}$ and gastric, small bowel, and colonic transit in constipated patients ${ }^{62}$. The initial phase 3, double-blind, parallel-group, placebo-controlled trials demonstrated that prucalopride was substantially more efficacious than placebo for increasing the number of spontaneous complete bowel movements by one per week $(47 \%$ versus $26 \%, p<0.001)$ and promoting more than three complete spontaneous bowel motions (CSBMs) per week (31\% versus $12 \%, p<0.001)$. Patients reported less-severe symptoms and improved satisfaction with their bowel function ${ }^{63}$. Subsequent findings include improved constipation-related quality of $\operatorname{life}^{64}$, satisfaction with prucalopride in patients who were dissatisfied with previous laxative treatments ${ }^{65,66}$, and efficacy for treating constipation in men ${ }^{67}$, elderly patients ${ }^{68}$, and patients with chronic intestinal pseudo-obstruction ${ }^{69}$, opioid-induced constipation ${ }^{70}$, or spinal cord injury ${ }^{71}$. Moreover, prucalopride remains efficacious after 18 months of therapy ${ }^{72}$. Only one study, a double-blind, placebo-controlled trial over 24 weeks, demonstrated no benefit above placebo $^{73}$. Even in older patients, the risk of cardiac events, including QT prolongation, is not increased ${ }^{74,75}$. Only 5\% 
of patients discontinue the medication because of adverse effects (for example, abdominal pain, nausea, diarrhea, or headache $)^{72}$. Prucalopride is approved by the European Medicines Agency (EMA), but not by the US Food and Drug Administration (FDA), for the treatment of constipation.

Velusetrag (TD-5108), a newer selective 5-HT(4) receptor agonist, accelerates colonic and gastric transit ${ }^{76,77}$. A phase 2 trial of about 400 patients demonstrated a significant increase above placebo in the number of spontaneous bowel motions (about 3.5 versus $1.4, p<0.001$ ) and CSBMs per week (about 2 versus $0.6, p<0.001)$ for all doses of velusetrag ${ }^{78}$. A phase 2 trial of naronapride (ATI-7505) demonstrated beneficial physiological and clinical effects ${ }^{79}$. These studies with velusetrag and ATI-7505 were published almost a decade ago. In November 2016, after a considerable delay, the FDA recommended that efficacy and cardiovascular safety of naronapride be evaluated in two additional phase 3 studies with 1,000 patients each ${ }^{80}$. However, no phase 3 trials of velusetrag for constipation are currently registered on ClinicalTrials.gov. Another highly selective 5-HT(4) receptor agonist, YH12852, accelerated upper and lower intestinal transit in animal models ${ }^{81}$. Human studies are awaited.

Intestinal chloride channel activators: lubiprostone, linaclotide, and plecanatide

The secretion of ions, and thereby fluid, into the intestinal lumen through ion channels can be pharmacologically driven by lubiprostone, linaclotide, and plecanatide. Activation of the cystic fibrosis transmembrane conductance regulator (CFTR) on the apical surface of enterocytes results in chloride secretion into the intestinal lumen, which is followed by a net secretion of sodium and subsequently water ${ }^{82}$.

Lubiprostone is a prostaglandin $\mathrm{E}$ analog that activates apical type 2 chloride channels, prostaglandin EP receptors, and the apical $\mathrm{CFTR}^{83}$. In a 4-week randomized parallel-group placebocontrolled phase 3 trial involving 237 patients with chronic constipation, lubiprostone (24 $\mu \mathrm{g}$ daily) was superior to placebo $^{84}$. Lubiprostone-treated patients experienced more frequent spontaneous bowel motions than those treated with placebo $(5.9$ versus $4.0, p<0.001)$. Lubiprostone reduced bloating ${ }^{85}$ but did not affect pain thresholds during colonic distention $^{86}$. It is efficacious for treating constipation associated with cystic fibrosis ${ }^{83}$, diabetes ${ }^{87}$, and opioids ${ }^{88}$. In general, lubiprostone is well tolerated. However, nausea (20\%), diarrhea (10\%), abdominal distension (7\%), headache (7\%), and abdominal pain $(5 \%)$ are reported frequently ${ }^{85}$.

Linaclotide and plecanatide are uroguanylin analogs that activate cell-surface guanylate cyclase-C receptors on enterocytes, inducing translocation of the CFTR to the apical surface of the cell. Initial studies of linaclotide demonstrated a dose-dependent increase in colonic transit with an associated increase in bowel motion frequency and consistency and reduced straining scores in patients with IBS- $\mathrm{C}^{89}$ and chronic constipation $^{90}$. Larger studies confirmed these findings, and only $4 \%$ of patients stopped the medication because of adverse side effects ${ }^{91-93}$. Linaclotide $145 \mu \mathrm{g}$ and $290 \mu \mathrm{g}$ increased the mean number of CSBMs per week to about 2.5 versus 0.9 with placebo $(p<0.001)^{92}$. In rodent models of visceral pain, linaclotide reduced visceral sensitivity ${ }^{94}$. Perhaps this explains, at least in part, why linaclotide reduced abdominal pain and improved bowel motion frequency and consistency in patients with IBS-C $\mathrm{C}^{95}$. These benefits appear to persist with longer-term administration ${ }^{96}$.

In 2017, plecanatide, which works via mechanisms similar to those of linaclotide, was approved by the FDA for treating chronic idiopathic constipation ${ }^{97}$ based on a phase 3 , multicenter, double-blind, placebo-controlled study of 1,394 patients ${ }^{98}$. Plecanatide increased the weekly number of CSBMs (about 2.2 versus 1.2, $p<0.001)$ and spontaneous bowel motions (about 3.1 versus $1.3, p<0.001$ ) per week above those seen with placebo during a 12-week study. Adverse effects (most commonly diarrhea) occurred in about $6 \%$ of patients taking plecanatide and $1 \%$ of patients receiving placebo. Similar findings were reported elsewhere ${ }^{99}$. An open-label follow-up study of 2,370 patients who had been enrolled in phase $2 b$ or phase 3 studies demonstrated that $82 \%$ had completed or were still receiving the study $\operatorname{drug}^{100}$. These patients reported a median satisfaction score for treatment of 4.0 (quite satisfied) and were "quite likely" to continue the medication. Animal models suggest that plecanatide, similar to linaclotide, also reduces visceral sensitivity ${ }^{101}$, and phase 3 trials in patients with IBS-C have demonstrated a significant improvement in bowel motion frequency, stool consistency, and abdominal pain above that seen with placebo ${ }^{102}$. Sustained response with the $6 \mathrm{mg}$ dose of plecanatide was seen in $30 \%$ of patients in the first study (placebo response $18 \%, p<0.001$ ) and $24 \%$ in the second trial $(14 \% \text { placebo response, } p<0.001)^{102}$. Additional CFTR activators (CFTRact-J027 and its derivatives) have demonstrated efficacy for treating constipation in mouse models ${ }^{103,104}$.

\section{Modifiers of bile acid recycling and synthesis: elobixibat} and NGM282

Elobixibat (A3309) is the first-in-class ileal bile acid transporter inhibitor ${ }^{105}$. Inhibiting the absorption of bile acids from the ileum exposes the colonic mucosa to a higher concentration of these ionic detergents. This accelerates colonic transit, increases stool frequency, and potentially relieves the symptoms of constipation $^{23,24,106}$. In a randomized phase $2 \mathrm{~b}$ trial, 190 patients with chronic constipation received 5, 10, or $15 \mathrm{mg}$ of elobixibat or placebo once daily for 8 weeks. The times to the first spontaneous bowel motion and CSBM were significantly shortened in the 10 and $15 \mathrm{mg}$ groups. Stool frequency and constipation-related symptoms were significantly improved ${ }^{107}$. A phase 3 trial confirmed the efficacy of elobixibat for the treatment of chronic constipation but demonstrated that adverse drug reactions occur in up to half of patients ${ }^{108}$. These are usually mild abdominal pain or diarrhea. Though approved for clinical use in Japan, elobixibat is not currently approved for use by the EMA or the FDA.

In patients with functional constipation, the fibroblast growth factor 19 analog NGM282 accelerated gastric and colonic transit, 
resulting in an increased number of bowel movements, looser stool form, and increased ease of stool passage ${ }^{25}$. The rationale for this study was the observation that NGM282 induced diarrhea in phase 2 trials relating to type 2 diabetes, primary biliary cholangitis, and non-alcoholic steatohepatitis. However, NGM282 is a potent inhibitor of bile acid synthesis, and in this study, in contrast to the effect of elobixibat, bile acid concentration in stool was reduced. Further physiological studies are needed to elucidate how NGM282 exerts its effects.

\section{Sodium/hydrogen exchanger inhibitors: tenapanor}

Tenapanor (AZD1722) is a first-in-class, minimally absorbed, small-molecule inhibitor of the gastrointestinal sodium/hydrogen exchanger NHE3. It inhibits the absorption of dietary sodium and phosphate, which increases intestinal fluid volume and transit ${ }^{109}$. The effect is more pronounced when tenapanor is administered pre-meal ${ }^{110}$. A phase 2 randomized placebocontrolled trial of 356 patients- $87 \%$ women, mean \pm standard deviation (SD) of $46 \pm 13$ years-with IBS-C demonstrated a CSBM responder rate of $61 \%$ with tenapanor $50 \mathrm{mg}$ twice a day as compared with $34 \%$ in the placebo group $(p<0.001)$. Additionally, abdominal pain was significantly reduced in the tenapanor group ${ }^{111}$. The most common adverse events were diarrhea, headache, nausea, urinary tract infection, and abdominal pain. Diarrhea occurred in $9 \%$ of patients and resulted in medication cessation in $3 \%$. Of note, data regarding the effect of tenapanor on hyperphosphatemia in patients with chronic kidney disease, which encompassed an older patient cohort (mean $\pm \mathrm{SD}$ of $59 \pm 14$ years), demonstrated a similar side effect profile ${ }^{112}$. Thereafter, two phase 3 trials in IBS-C, each with about 600 patients treated for 12 and 26 weeks, have been reported. In the first phase 3 trial, tenapanor met its primary endpoint (combined pain and stool pattern responder rate of $27 \%$ versus $19 \%$ with placebo, $p=0.02)^{113}$. Significance was met for the secondary endpoint of abdominal pain relief but not for the CSBM endpoint. In the second study, tenapanor met all primary and secondary endpoints ${ }^{114}$; the company plans to submit an application to the FDA in the second half of 2018. Tenapanor is not licensed by the EMA.

\section{New but not necessarily better}

Although these new agents are efficacious, only two studies have directly compared the clinical efficacy of newer and older laxatives. The first study compared polyethylene glycol with tegaserod, which has since been withdrawn from the market, in a randomized open-label, parallel-group study of 237 patients. Polyethylene glycol was better for improving symptoms of constipation. In the second, a randomized, double-blind, double-dummy study of 240 patients with chronic constipation, polyethylene glycol with electrolytes was compared with prucalopride $^{115}$. Polyethylene glycol with electrolytes was noninferior to prucalopride for promoting more than three CSBMs per week and was better tolerated.

Indeed, a network meta-analysis comparing prucalopride, lubiprostone, linaclotide, tegaserod, velusetrag, elobixibat, bisacodyl, and sodium picosulfate was undertaken, albeit with limited data for some medications, and observed that these drugs were of comparable efficacy for the endpoints of at least three
CSBMs per week or an increase over baseline of at least one CSBM per week. Bisacodyl was superior to the other agents for inducing a greater change from baseline in the number of spontaneous bowel motions per week ${ }^{116}$.

Furthermore, the newer laxatives are much more expensive than the older, over-the-counter agents. In the United States, a 30-day supply of lubiprostone, linaclotide, or plecanatide costs about $\$ 450$. By comparison, a 30-day supply of psyllium, polyethylene glycol, bisacodyl, or senna costs less than $\$ 10$, whereas lactulose costs less than $\$ 15$.

\section{Optimizing therapy and the potential role for individualized treatment of constipation}

Consensus guidelines recommend that pelvic floor biofeedback therapy, not laxatives, is the cornerstone for managing defecatory disorders ${ }^{8}$. However, none of the pharmacological studies described above rigorously evaluated anorectal function and excluded patients with defecatory disorders. Therefore, the relative efficacy of these drugs in patients with isolated normal or slow transit constipation is unknown.

Where constipation does not respond to empiric therapy and a defecatory disorder has been excluded, investigation could guide tailored therapy. For example, the 5-HT(4) receptor agonist prucalopride might be a preferential choice for patients with diffusely slow intestinal transit. Ileal bile acid transporter inhibitors could be of benefit for constipated patients with a deficiency of bile acids reaching the colon. A single case report observed that mexiletine normalized bowel functions in a patient with IBS-C and a mutation in the $S C N 5 A$ gene, which encodes the alpha-subunit of the voltage-gated sodium channel $\mathrm{Na}_{\mathrm{v}} 1.5^{20}$.

Future studies should evaluate the efficacy of novel and standard laxatives in patients with defined normal or slow transit constipation and the efficacy of targeted therapy (for example, with ileal bile acid transporter inhibitors in constipated patients with a deficiency of bile acids reaching the colon).

\section{Summary and conclusions}

Constipation is common, but the underlying pathophysiology remains unclear in many cases. Many patients can be effectively and inexpensively treated with simple laxatives. Newer intestinal secretagogues and promotility agents are more expensive and should be considered in patients who do not respond to simple laxatives. A few new agents are being evaluated in clinical trials. There is a critical need to compare the efficacy of these newer agents relative to established laxatives and also clarify their efficacy in the subtypes of constipation (that is, normal transit, slow transit, and defecatory disorders).

Grant information

This work was supported in part by US Public Health Service National Institutes of Health grant P01 DK68055.

The funders had no role in study design, data collection and analysis, decision to publish, or preparation of the manuscript. 
1. Mugie SM, Benninga MA, Di Lorenzo C: Epidemiology of constipation in children and adults: a systematic review. Best Pract Res Clin Gastroenterol. 2011; 25(1): 3-18.

PubMed Abstract | Publisher Full Text

2. Mearin F, Lacy BE, Chang L, et al.: Bowel Disorders. Gastroenterology. 2016; pii: S0016-5085(16)00222-5.

PubMed Abstract | Publisher Full Text

3. Belsey J, Greenfield S, Candy D, et al:: Systematic review: impact of constipation on quality of life in adults and children. Aliment Pharmacol Ther 2010; 31(9): 938-49.

PubMed Abstract | Publisher Full Text

4. Heidelbaugh JJ, Stelwagon M, Miller SA, et al:: The spectrum of constipationpredominant irritable bowel syndrome and chronic idiopathic constipation: US survey assessing symptoms, care seeking, and disease burden. $A m J$ Gastroenterol. 2015; 110(4): 580-7.

PubMed Abstract | Publisher Full Text | Free Full Text

5. Drossman DA, Li Z, Andruzzi E, Temple RD, et al.: U.S. householder survey of functional gastrointestinal disorders. Prevalence, sociodemography, and health impact. Dig Dis Sci. 1993; 38(9): 1569-80.

PubMed Abstract | Publisher Full Text

6. Shah ND, Chitkara DK, Locke GR, et al.: Ambulatory care for constipation in the United States, 1993-2004. Am J Gastroenterol. 2008; 103(7): 1746-53. PubMed Abstract | Publisher Full Text

7. Martin BC, Barghout V, Cerulli A: Direct medical costs of constipation in the United States. Manag Care Interface. 2006; 19(12): 43-9. PubMed Abstract

8. Bharucha AE, Pemberton JH, Locke GR 3rd: American Gastroenterological Association technical review on constipation. Gastroenterology. 2013; 144(1): 218-38.

PubMed Abstract | Publisher Full Text | Free Full Text

9. Wald $A$, Bharucha $A E$, Cosman $B C$, et al.: ACG clinical guideline: management of benign anorectal disorders. Am J Gastroenterol. 2014; 109(8): 1141-57; (Quiz) 1058.

PubMed Abstract | Publisher Full Text

10. Degen LP, Phillips SF: How well does stool form reflect colonic transit? Gut. 1996; 39(1): 109-13.

PubMed Abstract | Publisher Full Text | Free Full Text

11. Shafe AC, Lee S, Dalrymple JS, et al:: The LUCK study: Laxative Usage in patients with GP-diagnosed Constipation in the UK, within the general population and in pregnancy. An epidemiological study using the Genera Practice Research Database (GPRD). Therap Adv Gastroenterol. 2011; 4(6): 343-63.

PubMed Abstract | Publisher Full Text | Free Full Text

12. Menees SB, Guentner A, Chey SW, et al.: How Do US Gastroenterologists Use Over-the-Counter and Prescription Medications in Patients With Gastroesophageal Reflux and Chronic Constipation? Am J Gastroenterol. 2015; 110(11): 1516-25.

PubMed Abstract | Publisher Full Text

13. Paré $P$, Fedorak RN: Systematic review of stimulant and nonstimulant laxatives for the treatment of functional constipation. Can J Gastroenterol Hepatol. 2014; 28(10): 549-57.

PubMed Abstract | Publisher Full Text | Free Full Text

14. Müller-Lissner S, Tack J, Feng Y, et al:: Levels of satisfaction with current chronic constipation treatment options in Europe - an internet survey. Aliment Pharmacol Ther. 2013; 37(1): 137-45.

PubMed Abstract | Publisher Full Text

15. Emmanuel A, Quigley EM, Simrén M, et al:: Factors affecting satisfaction with treatment in European women with chronic constipation: An internet survey. United European Gastroenterol J. 2013; 1(5): 375-84. PubMed Abstract | Publisher Full Text | Free Full Text

16. Noelting J, Eaton JE, Choung RS, et al.: The incidence rate and characteristics of clinically diagnosed defecatory disorders in the community. Neurogastroenterol Motil. 2016; 28(11): 1690-7.

PubMed Abstract | Publisher Full Text | Free Full Text

17. Rao SS, Mudipalli RS, Stessman M, et al.: Investigation of the utility of colorectal function tests and Rome II criteria in dyssynergic defecation (Anismus). Neurogastroenterol Motil. 2004; 16(5): 589-96.

PubMed Abstract | Publisher Full Text

18. Chiarioni G, Salandini L, Whitehead WE: Biofeedback benefits only patients with outlet dysfunction, not patients with isolated slow transit constipation. Gastroenterology. 2005; 129(1): 86-97. PubMed Abstract | Publisher Full Text

19. F Beyder A, Farrugia G: Ion channelopathies in functional GI disorders. $A m$ Physiol Gastrointest Liver Physiol. 2016; 311(4): G581-G586. PubMed Abstract | Publisher Full Text | Free Full Text | F1000 Recommendation

20. F Beyder A, Mazzone A, Strege PR, et al.: Loss-of-function of the voltagegated sodium channel NaV1.5 (channelopathies) in patients with irritable bowel syndrome. Gastroenterology. 2014; 146(7): 1659-68. PubMed Abstract | Publisher Full Text | Free Full Text | F1000 Recommendation
21. Slattery SA, Niaz O, Aziz Q, et al.: Systematic review with meta-analysis: the prevalence of bile acid malabsorption in the irritable bowel syndrome with diarrhoea. Aliment Pharmacol Ther. 2015; 42(1): 3-11. PubMed Abstract | Publisher Full Text

22. F Vijayvargiya P, Busciglio I, Burton D, et al.: Bile Acid Deficiency in a Subgroup of Patients With Irritable Bowel Syndrome With Constipation Based on Biomarkers in Serum and Fecal Samples. Clin Gastroenterol Hepatol. 2018: 16(4): 522-7.

PubMed Abstract | Publisher Full Text | Free Full Text | F1000 Recommendation

23. Thaysen EH, Pedersen L: Idiopathic bile acid catharsis. Gut. 1976; 17(12): $965-70$

PubMed Abstract | Publisher Full Text | Free Full Text

24. F Rao AS, Wong BS, Camilleri M, et al:: Chenodeoxycholate in females with irritable bowel syndrome-constipation: a pharmacodynamic and pharmacogenetic analysis. Gastroenterology. 2010; 139(5): 1549-58, 1558.e1. PubMed Abstract | Publisher Full Text | Free Full Text | F1000 Recommendation

25. F Oduyebo I, Camilleri M, Nelson AD, et al:: Effects of NGM282, an FGF19 variant, on colonic transit and bowel function in functional constipation: a randomized phase 2 trial. Am J Gastroenterol. 2018; 113(5): 725-34. PubMed Abstract | Publisher Full Text | F1000 Recommendation

26. Bharucha AE: Pelvic floor: anatomy and function. Neurogastroenterol Motil. 2006; 18(7): 507-19.

PubMed Abstract | Publisher Full Text

27. F Ratuapli SK, Bharucha AE, Noelting J, et al:: Phenotypic identification and classification of functional defecatory disorders using high-resolution anorectal manometry. Gastroenterology. 2013; 144(2): 314-322.e2.

PubMed Abstract | Publisher Full Text | Free Full Text | F1000 Recommendation

28. Rao SSC: Rectal Exam: Yes, it can and should be done in a busy practice! $A m \mathrm{~J}$ Gastroenterol. 2018; 113(5): 635-8.

PubMed Abstract | Publisher Full Text

29. Tantiphlachiva K, Rao P, Attaluri A, et al:: Digital rectal examination is a useful tool for identifying patients with dyssynergia. Clin Gastroenterol Hepatol. 2010 8(11): 955-60.

PubMed Abstract | Publisher Full Text

30. Soh JS, Lee HJ, Jung KW, et al.: The diagnostic value of a digital rectal examination compared with high-resolution anorectal manometry in patients with chronic constipation and fecal incontinence. Am J Gastroenterol. 2015 110(8): 1197-204.

PubMed Abstract | Publisher Full Text

31. Carrington EV, Scott SM, Bharucha A, et al.: Expert consensus document: Advances in the evaluation of anorectal function. Nat Rev Gastroenterol Hepatol. 2018; 15(5): 309-23.

PubMed Abstract | Publisher Full Text | Free Full Text

32. Rao SS, Bharucha AE, Chiarioni G, et al.: Functional Anorectal Disorders. Gastroenterology. 2016; 150(6): 1430-1442.e4, pii: S0016-5085(16)00175-X. PubMed Abstract | Publisher Full Text | Free Full Text

33. Basilisco G, Bharucha AE: High-resolution anorectal manometry: An expensive hobby or worth every penny? Neurogastroenterol Motil. 2017; 29(8): e13125. PubMed Abstract | Publisher Full Text | Free Full Text

34. Kang HR, Lee JE, Lee JS, et al.: Comparison of High-resolution Anorectal Manometry With Water-perfused Anorectal Manometry. J Neurogastroenterol Motil. 2015; 21(1): 126-32.

PubMed Abstract | Publisher Full Text | Free Full Text

35. Chakraborty S, Feuerhak KJ, Zinsmeister AR, et al: Reproducibility of high definition (3D) manometry and its agreement with high-resolution (2D) manometry in women with fecal incontinence. Neurogastroenterol Motil. 2017; 29(3): e12950.

PubMed Abstract | Publisher Full Text | Free Full Text

36. F Mion F, Garros A, Brochard C, et al:: 3D High-definition anorectal manometry: Values obtained in asymptomatic volunteers, fecal incontinence and chronic constipation. Results of a prospective multicenter study (NOMAD). Neurogastroenterol Motil. 2017; 29(8): e13049. PubMed Abstract | Publisher Full Text | F1000 Recommendation

37. F Heinrich $\mathrm{H}$, Sauter M, Fox M, et al:: Assessment of Obstructive Defecation by High-Resolution Anorectal Manometry Compared With Magnetic Resonance Defecography. Clin Gastroenterol Hepatol. 2015; 13(7): 1310-1317.e1. PubMed Abstract | Publisher Full Text | F1000 Recommendation

38. Prichard DO, Lee T, Parthasarathy G, et al.: High-resolution Anorectal Manometry for Identifying Defecatory Disorders and Rectal Structural Abnormalities in Women. Clin Gastroenterol Hepatol. 2017; 15(3): 412-20. PubMed Abstract | Publisher Full Text | Free Full Text

39. Brusciano L, Tolone S, Limongelli $P$, et al: Anatomical and Functional Features of the Internal Rectal Prolapse With Outlet Obstruction Determined With 3D Endorectal Ultrasonography and High-Resolution Anorectal Manometry: An Observational Case-Control Study. Am J Gastroenterol. 2018; 113(8): 1247-50. PubMed Abstract | Publisher Full Text

40. F Benezech A, Cappiello M, Baumstarck K, et al.: Rectal intussusception 
can high resolution three-dimensional ano-rectal manometry compete with conventional defecography? Neurogastroenterol Motil. 2017; 29(4): e12978. PubMed Abstract | Publisher Full Text | F1000 Recommendation

41. Corsetti M, Pagliaro G, Demedts I, et al:: Pan-Colonic Pressurizations Associated With Relaxation of the Anal Sphincter in Health and Disease: A New Colonic Motor Pattern Identified Using High-Resolution Manometry. Am J Gastroenterol. 2017; 112(3): 479-89.

PubMed Abstract | Publisher Full Text

42. Giorgio V, Borrelli O, Smith VV, et al:: High-resolution colonic manometry accurately predicts colonic neuromuscular pathological phenotype in pediatric slow transit constipation. Neurogastroenterol Motil. 2013; 25(1): 70-8.e8-9.

PubMed Abstract | Publisher Full Text

43. Pilkington SA, Nugent KP, Brenner J, et al.: Barium proctography vs magnetic resonance proctography for pelvic floor disorders: a comparative study. Colorectal Dis. 2012; 14(10): 1224-30.

PubMed Abstract | Publisher Full Text

44. van lersel JJ, Formijne Jonkers HA, Verheijen PM, et al.: Comparison of dynamic magnetic resonance defaecography with rectal contrast and conventional defaecography for posterior pelvic floor compartment prolapse. Colorectal Dis. 2017; 19(1): O46-O53.

PubMed Abstract | Publisher Full Text

45. Zafar A, Seretis C, Feretis M, et al.: Comparative study of magnetic resonance defaecography and evacuation proctography in the evaluation of obstructed defaecation. Colorectal Dis. 2017; 19(6): O204-O209.

PubMed Abstract | Publisher Full Tex

46. Nilsson M, Sandberg TH, Poulsen JL, et al:: Quantification and variability in colonic volume with a novel magnetic resonance imaging method. Neurogastroenterol Motil. 2015; 27(12): 1755-63.

PubMed Abstract | Publisher Full Text

47. Sandberg TH, Nilsson M, Poulsen JL, et al:: A novel semi-automatic segmentation method for volumetric assessment of the colon based on magnetic resonance imaging. Abdom Imaging. 2015; 40(7): 2232-41. PubMed Abstract | Publisher Full Text

48. Lam C, Chaddock G, Marciani L, et al:: Colonic response to laxative ingestion as assessed by MRI differs in constipated irritable bowel syndrome compared to functional constipation. Neurogastroenterol Motil. 2016; 28(6): 861-70. PubMed Abstract | Publisher Full Text | Free Full Text

49. Inoh $\mathrm{Y}, \mathrm{Kanoshima} \mathrm{K}$, Ohkuma $\mathrm{K}$, et al:: Assessment of colonic contents in patients with chronic constipation using MRI. J Clin Biochem Nutr. 2018; 62(3): $277-80$.

PubMed Abstract | Publisher Full Text | Free Full Text

50. F Park SY, Khemani D, Acosta A, et al.: Rectal gas volume: Defining cutoffs for screening for evacuation disorders in patients with constipation. Neurogastroenterol Motil. 2017; 29(7): e13044.

PubMed Abstract | Publisher Full Text | Free Full Text | F1000 Recommendation

51. Park SY, Khemani D, Nelson AD, et al.: Rectal Gas Volume Measured by Computerized Tomography Identifies Evacuation Disorders in Patients With Constipation. Clin Gastroenterol Hepatol. 2017; 15(4): 543-552.e4. PubMed Abstract | Publisher Full Text | Free Full Text

52. Quigley EM: Cisapride: what can we learn from the rise and fall of a prokinetic? J Dig Dis. 2011; 12(3): 147-56

PubMed Abstract | Publisher Full Text

53. Chey WD: Review article: tegaserod -- the global experience. Aliment Pharmacol Ther. 2004; 20 Suppl 7: 15-9.

PubMed Abstract | Publisher Full Text

54. Hennessy S, Leonard CE, Newcomb C, et al:: Cisapride and ventricular arrhythmia. Br J Clin Pharmacol. 2008; 66(3): 375-85. PubMed Abstract | Publisher Full Text | Free Full Text

55. Wysowski DK, Corken A, Gallo-Torres H, et al.: Postmarketing reports of QT prolongation and ventricular arrhythmia in association with cisapride and Food and Drug Administration regulatory actions. Am J Gastroenterol. 2001; 96(6): 1698-703

PubMed Abstract | Publisher Full Tex

56. Thompson CA: Novartis suspends tegaserod sales at FDA's request. Am J Health Syst Pharm. 2007; 64(10): 1020. PubMed Abstract | Publisher Full Tex

57. Potet $F$, Bouyssou T, Escande D, et al:: Gastrointestinal prokinetic drugs have different affinity for the human cardiac human ether-à-gogo $\mathrm{K}^{+}$channel. J Pharmacol Exp Ther. 2001; 299(3): 1007-12.

PubMed Abstract

58. Rampe D, Roy ML, Dennis A, et al:: A mechanism for the proarrhythmic effects of cisapride (Propulsid): high affinity blockade of the human cardiac potassium channel HERG. FEBS Lett. 1997; 417(1): 28-32. PubMed Abstract | Publisher Full Tex

59. Bharucha AE, Wouters MM, Tack J: Existing and emerging therapies for managing constipation and diarrhea. Curr Opin Pharmacol. 2017; 37: 158-66. PubMed Abstract | Publisher Full Text | Free Full Text

60. Bouras EP, Camilleri M, Burton DD, et al:: Selective stimulation of colonic transit by the benzofuran $5 \mathrm{HT}_{4}$ agonist, prucalopride, in healthy humans. Gut. 1999 44(5): 682-6.

PubMed Abstract | Publisher Full Text | Free Full Text

61. Miner PB Jr, Camilleri M, Burton D, et al:: Prucalopride induces high-amplitude propagating contractions in the colon of patients with chronic constipation: a randomized study. Neurogastroenterol Motil. 2016; 28(9): 1341-8.

PubMed Abstract | Publisher Full Text

62. Bouras EP, Camilleri M, Burton DD, et al:: Prucalopride accelerates gastrointestinal and colonic transit in patients with constipation without a rectal evacuation disorder. Gastroenterology. 2001; 120(2): 354-60. PubMed Abstract | Publisher Full Text

63. F Camilleri M, Kerstens R, Rykx A, et al:: A placebo-controlled trial of prucalopride for severe chronic constipation. N Engl J Med. 2008; 358(22): 2344-54.

PubMed Abstract | Publisher Full Text | F1000 Recommendation

64. Quigley EM, Vandeplassche L, Kerstens R, et al.: Clinical trial: the efficacy, impact on quality of life, and safety and tolerability of prucalopride in severe chronic constipation--a 12-week, randomized, double-blind, placebo-controlled study. Aliment Pharmacol Ther. 2009; 29(3): 315-28.

PubMed Abstract | Publisher Full Text

65. Tack J, van Outryve M, Beyens G, et al:: Prucalopride (Resolor) in the treatment of severe chronic constipation in patients dissatisfied with laxatives. Gut. 2009; 58(3): 357-65.

PubMed Abstract | Publisher Full Text

66. Tack J, Quigley E, Camilleri M, et al.: Efficacy and safety of oral prucalopride in women with chronic constipation in whom laxatives have failed: an integrated analysis. United European Gastroenterol J. 2013; 1(1): 48-59. PubMed Abstract | Publisher Full Text | Free Full Text

67. F Yiannakou $\mathrm{Y}$, Piessevaux $\mathrm{H}$, Bouchoucha $\mathrm{M}$, et al:: A randomized, doubleblind, placebo-controlled, phase 3 trial to evaluate the efficacy, safety, and tolerability of prucalopride in men with chronic constipation. $\mathrm{Am}$ Gastroenterol. 2015; 110(5): 741-8.

PubMed Abstract | Publisher Full Text | Free Full Text | F1000 Recommendation

68. Müller-Lissner S, Rykx A, Kerstens R, et al:: A double-blind, placebo-controlled study of prucalopride in elderly patients with chronic constipation.

Neurogastroenterol Motil. 2010; 22(9): 991-8, e255.

PubMed Abstract | Publisher Full Text

69. Emmanuel AV, Kamm MA, Roy AJ, et al:: Randomised clinical trial: the efficacy of prucalopride in patients with chronic intestinal pseudo-obstruction--a double-blind, placebo-controlled, cross-over, multiple $n=1$ study. Aliment Pharmacol Ther. 2012; 35(1): 48-55.

PubMed Abstract | Publisher Full Text | Free Full Text

70. Sloots CE, Rykx A, Cools M, et al.: Efficacy and safety of prucalopride in patients with chronic noncancer pain suffering from opioid-induced constipation. Dig Dis Sci. 2010; 55(10): 2912-21.

PubMed Abstract | Publisher Full Text | Free Full Text

71. Krogh K, Jensen MB, Gandrup P, et al:: Efficacy and tolerability of prucalopride in patients with constipation due to spinal cord injury. Scand $J$ Gastroenterol. 2002; 37(4): 431-6.

PubMed Abstract | Publisher Full Text

72. Camilleri M, Van Outryve MJ, Beyens G, et al.: Clinical trial: the efficacy of openlabel prucalopride treatment in patients with chronic constipation - follow-up of patients from the pivotal studies. Aliment Pharmacol Ther. 2010; 32(9): 1113-23. PubMed Abstract | Publisher Full Text

73. Piessevaux H, Corazziari E, Rey E, et al:: A randomized, double-blind, placebocontrolled trial to evaluate the efficacy, safety, and tolerability of long-term treatment with prucalopride. Neurogastroenterol Motil. 2015; 27(6): 805-15. PubMed Abstract | Publisher Full Text

74. Mendzelevski B, Ausma J, Chanter DO, et al.: Assessment of the cardiac safety of prucalopride in healthy volunteers: a randomized, double-blind, placeboand positive-controlled thorough QT study. Br J Clin Pharmacol. 2012; 73(2): 203-9.

PubMed Abstract | Publisher Full Text | Free Full Text

75. Camilleri M, Beyens G, Kerstens R, et al:: Safety assessment of prucalopride in elderly patients with constipation: a double-blind, placebo-controlled study. Neurogastroenterol Motil. 2009; 21(12): 1256-e117.

PubMed Abstract | Publisher Full Text

76. Manini ML, Camilleri M, Goldberg M, et al:: Effects of Velusetrag (TD-5108) on gastrointestinal transit and bowel function in health and pharmacokinetics in health and constipation. Neurogastroenterol Motil. 2010; 22(1): 42-9, e7-8. PubMed Abstract | Publisher Full Text | Free Full Text

77. F Bassotti G, Gambaccini D, Bellini M: Velusetrag for the treatment of chronic constipation. Expert Opin Investig Drugs. 2016; 25(8): 985-90. PubMed Abstract | Publisher Full Text | F1000 Recommendation

78. Goldberg M, Li YP, Johanson JF, et al:: Clinical trial: the efficacy and tolerability of velusetrag, a selective 5-HT, agonist with high intrinsic activity, in chronic idiopathic constipation - a 4-week, randomized, double-blind, placebocontrolled, dose-response study. Aliment Pharmacol Ther. 2010; 32(9): 1102-12. PubMed Abstract | Publisher Full Text

79. Camilleri M, Vazquez-Roque MI, Burton D, et al:: Pharmacodynamic effects of a novel prokinetic 5-HT receptor agonist, ATI-7505, in humans. Neurogastroenterol Motil. 2007; 19(1): 30-8. PubMed Abstract | Publisher Full Text

80. Renexxion Achieves Positive FDA Guidance for Phase 3-ready GI Drug Naronapride. 2016; [cited 2018 7th August] Reference Source

81. Jeong EJ, Chung SY, Hong HN, et al.: The novel, potent and highly selective 
5- $\mathrm{HT}_{4}$ receptor agonist $\mathrm{YH} 12852$ significantly improves both upper and lower gastrointestinal motility. Br J Pharmacol. 2018; 175(3): 485-500. PubMed Abstract | Publisher Full Text | Free Full Text

82. Ahsan MK, Tchernychev B, Kessler MM, et al:: Linaclotide activates guanylate cyclase-C/cGMP/protein kinase-II-dependent trafficking of CFTR in the intestine. Physiol Rep. 2017; 5(11): pii: e13299. PubMed Abstract | Publisher Full Text | Free Full Text

83. Norimatsu Y, Moran AR, MacDonald KD: Lubiprostone activates CFTR, but not CIC-2, via the prostaglandin receptor $\left(\mathrm{EP}_{4}\right)$. Biochem Biophys Res Commun. 2012; 426(3): 374-9.

PubMed Abstract | Publisher Full Text | Free Full Text

84. Barish CF, Drossman D, Johanson JF, et al:: Efficacy and safety of lubiprostone in patients with chronic constipation. Dig Dis Sci. 2010; 55(4): 1090-7. PubMed Abstract | Publisher Full Text

85. Lembo AJ, Johanson JF, Parkman HP, et al.: Long-term safety and effectiveness of lubiprostone, a chloride channel (CIC-2) activator, in patients with chronic idiopathic constipation. Dig Dis Sci. 2011; 56(9): 2639-45. PubMed Abstract | Publisher Full Text | Free Full Text

86. Whitehead WE, Palsson OS, Gangarosa L, et al.: Lubiprostone does not influence visceral pain thresholds in patients with irritable bowel syndrome. Neurogastroenterol Motil. 2011; 23(10): 944-e400.

PubMled Abstract | Publisher Full Text | Free Full Text

87. Christie J, Shroff S, Shahnavaz N, et al: A Randomized, Double-Blind, PlaceboControlled Trial to Examine the Effectiveness of Lubiprostone on Constipation Symptoms and Colon Transit Time in Diabetic Patients. Am J Gastroenterol. 2017; 112(2): 356-64. PubMed Abstract | Publisher Full Text

88. F Webster LR, Brewer RP, Lichtlen P, et al.: Efficacy of Lubiprostone for the Treatment of Opioid-Induced Constipation, Analyzed by Opioid Class. Pain Med. 2018; 19(6): 1195-205.

PubMed Abstract | Publisher Full Text | F1000 Recommendation

89. Andresen V, Camilleri M, Busciglio IA, et al.: Effect of $\mathbf{5}$ days linaclotide on transit and bowel function in females with constipation-predominant irritable bowel syndrome. Gastroenterology. 2007; 133(3): 761-8. PubMed Abstract | Publisher Full Text

90. Johnston JM, Kurtz CB, Drossman DA, et al:: Pilot study on the effect of linaclotide in patients with chronic constipation. Am J Gastroenterol. 2009; 104(1): 125-32.

PubMed Abstract | Publisher Full Text

91. F Lembo AJ, Kurtz CB, MacDougall JE, et al:: Efficacy of linaclotide for patients with chronic constipation. Gastroenterology. 2010; 138(3): 886-95.e1. PubMed Abstract | Publisher Full Text | F1000 Recommendation

92. F Lembo AJ, Schneier HA, Shiff SJ, et al:: Two randomized trials of linaclotide for chronic constipation. N Engl J Med. 2011; 365(6): 527-36. PubMed Abstract | Publisher Full Text | F1000 Recommendation

93. Bassotti G, Usai-Satta P, Bellini M: Linaclotide for the treatment of chronic constipation. Expert Opin Pharmacother. 2018; 19(11): 1261-6. PubMed Abstract | Publisher Full Text

94. Eutamene H, Bradesi S, Larauche M, et al.: Guanylate cyclase C-mediated antinociceptive effects of linaclotide in rodent models of visceral pain. Neurogastroenterol Motil. 2010; 22(3): 312-e84. PubMed Abstract | Publisher Full Text

95. F Johnston JM, Kurtz CB, MacDougall JE, et al:: Linaclotide improves abdominal pain and bowel habits in a phase llb study of patients with irritable bowel syndrome with constipation. Gastroenterology. 2010; 139(6): 1877-1886.e2. PubMed Abstract | Publisher Full Text | F1000 Recommendation

96. F Chey WD, Lembo AJ, Lavins BJ, et al.: Linaclotide for irritable bowel syndrome with constipation: a 26-week, randomized, double-blind, placebocontrolled trial to evaluate efficacy and safety. Am J Gastroenterol. 2012; 107(11): 1702-12.

PubMed Abstract | Publisher Full Text | F1000 Recommendation

97. Al-Salama ZT, Syed YY: Plecanatide: First Global Approval. Drugs. 2017; 77(5): 593-8.

PubMed Abstract | Publisher Full Text

98. F Miner PB Jr, Koltun WD, Wiener GJ, et al.: A Randomized Phase III Clinical Trial of Plecanatide, a Uroguanylin Analog, in Patients With Chronic Idiopathic Constipation. Am J Gastroenterol. 2017; 112(4): 613-21. PubMed Abstract | Publisher Full Text | Free Full Text | F1000 Recommendation

99. DeMicco M, Barrow L, Hickey B, et al:: Randomized clinical trial: efficacy and safety of plecanatide in the treatment of chronic idiopathic constipation.
Therap Adv Gastroenterol. 2017; 10(11): 837-51

PubMed Abstract | Publisher Full Text | Free Full Text

100. Barish CF, Griffin P: Safety and tolerability of plecanatide in patients with chronic idiopathic constipation: long-term evidence from an open-label study. Curr Med Res Opin. 2018; 34(4): 751-5. PubMed Abstract | Publisher Full Tex

101. Boulete IM, Thadi A, Beaufrand C, et al: Oral treatment with plecanatide or dolcanatide attenuates visceral hypersensitivity via activation of guanylate cyclase-C in rat models. World J Gastroenterol. 2018; 24(17): 1888-900. PubMed Abstract | Publisher Full Text | Free Full Text

102. Brenner DM, Fogel R, Dorn SD, et al.: Efficacy, safety, and tolerability of plecanatide in patients with irritable bowel syndrome with constipation: results of two phase 3 randomized clinical trials. Am J Gastroenterol. 2018; 113(5): 735-45.

PubMed Abstract | Publisher Full Text

103. Cil O, Phuan PW, Lee S, et al: CFTR activator increases intestinal fluid secretion and normalizes stool output in a mouse model of constipation. Cell Mol Gastroenterol Hepatol. 2016; 2(3): 317-27. PubMed Abstract | Publisher Full Text | Free Full Text

104. Son JH, Zhu JS, Phuan PW, et al:: High-Potency Phenylquinoxalinone Cystic Fibrosis Transmembrane Conductance Regulator (CFTR) Activators. J Med Chem. 2017; 60(6): 2401-10.

PubMed Abstract | Publisher Full Text | Free Full Text

105. Wong BS, Camilleri M: Elobixibat for the treatment of constipation. Expert Opin Investig Drugs. 2013; 22(2): 277-84. PubMed Abstract | Publisher Full Text

106. Rudling M, Camilleri M, Graffner $\mathrm{H}$, et al.: Specific inhibition of bile acid transport alters plasma lipids and GLP-1. BMC Cardiovasc Disord. 2015; 15: 75. PubMed Abstract | Publisher Full Text | Free Full Text

107. F Chey WD, Camilleri M, Chang L, et al:: A randomized placebo-controlled phase Ilb trial of a3309, a bile acid transporter inhibitor, for chronic idiopathic constipation. Am J Gastroenterol. 2011; 106(10): 1803-12. PubMed Abstract | Publisher Full Text | Free Full Text | F1000 Recommendation

108. F Nakajima A, Seki M, Taniguchi S, et al.: Safety and efficacy of elobixibat for chronic constipation: results from a randomised, double-blind, placebocontrolled, phase 3 trial and an open-label, single-arm, phase 3 trial. Lancet Gastroenterol Hepatol. 2018; 3(8): 537-47.

PubMed Abstract | Publisher Full Text | F1000 Recommendation

109. Rosenbaum DP, Yan A, Jacobs JW: Pharmacodynamics, Safety, and Tolerability of the NHE3 Inhibitor Tenapanor: Two Trials in Healthy Volunteers. Clin Drug Investig. 2018; 38(4): 341-51.

PubMed Abstract | Publisher Full Text | Free Full Text

110. Johansson SA, Knutsson M, Leonsson-Zachrisson M, et al.: Effect of Food Intake on the Pharmacodynamics of Tenapanor: A Phase 1 Study. Clin Pharmacol Drug Dev. 2017; 6(5): 457-65.

PubMed Abstract | Publisher Full Text | Free Full Tex

111. F Chey WD, Lembo AJ, Rosenbaum DP: Tenapanor Treatment of Patients With Constipation-Predominant Irritable Bowel Syndrome: A Phase 2, Randomized, Placebo-Controlled Efficacy and Safety Trial. Am J Gastroenterol. 2017; 112(5): 763-74.

PubMed Abstract | Publisher Full Text | Free Full Text | F1000 Recommendation

112. Block GA, Rosenbaum DP, Leonsson-Zachrisson M, et al.: Effect of Tenapanor on Serum Phosphate in Patients Receiving Hemodialysis. J Am Soc Nephrol. 2017 28(6): 1933-42.

PubMed Abstract | Publisher Full Text | Free Full Text

113. Ardelyx Reports Successful Phase 3 T3MPO-1 Trial of Tenapanor in Patients with IBS-C. 2017; [cited 2018 18th July] Reference Source

114. Ardelyx's Pivotal Phase 3 Study of Tenapanor for IBS-C Hits Primary and All Secondary Endpoints to Support NDA Submission in 2018. 2017; [cited 2018 18th July].

Reference Source

115. F Cinca R, Chera D, Gruss HJ, et al:: Randomised clinical trial: macrogol/PEG $3350+$ electrolytes versus prucalopride in the treatment of chronic constipation -- a comparison in a controlled environment. Aliment Pharmacol Ther. 2013; 37(9): 876-86 PubMed Abstract | Publisher Full Text | F1000 Recommendation

116. $\mathrm{F}$ Nelson $\mathrm{AD}$, Camilleri $\mathrm{M}$, Chirapongsathorn $\mathrm{S}$, et al:: Comparison of efficacy of pharmacological treatments for chronic idiopathic constipation: a systematic review and network meta-analysis. Gut. 2017; 66(9): 1611-22. PubMled Abstract | Publisher Full Text | F1000 Recommendation 


\section{Open Peer Review}

\section{Current Peer Review Status:}

\section{Editorial Note on the Review Process}

Faculty Reviews are review articles written by the prestigious Members of Faculty Opinions. The articles are commissioned and peer reviewed before publication to ensure that the final, published version is comprehensive and accessible. The reviewers who approved the final version are listed with their names and affiliations.

\section{The reviewers who approved this article are:}

\section{Version 1}

\section{Eamonn M. M. Quigley}

Houston Methodist Hospital, Houston, TX, USA

Competing Interests: No competing interests were disclosed.

\section{Massimo Bellini}

Gastrointestinal Unit, Department of Gastroenterology, University of Pisa, Pisa, Italy

Competing Interests: No competing interests were disclosed.

The benefits of publishing with F1000Research:

- Your article is published within days, with no editorial bias

- You can publish traditional articles, null/negative results, case reports, data notes and more

- The peer review process is transparent and collaborative

- Your article is indexed in PubMed after passing peer review

- Dedicated customer support at every stage

For pre-submission enquiries, contact research@f1000.com 